Zagadnienia Rodzajów Literackich, LXI, z. 1

PL ISSN 0084-4446

DOI: https://doi.org/10.26485/ZRL/2018/61.1/6

Ewa KujawsKa-Lis

Uniwersytet Warmińsko-Mazurski w Olsztynie*

\title{
Alliteration as a Means to Reinforce Orality in Conrad's Early Marlow Narratives
}

\begin{abstract}
Joseph Conrad's narratives featuring Marlow are composed as stories within stories, in which Marlow (the intradiegetic narrator) tells stories to his few listeners (the intradiegetic addresses). Critics have found analogies of these narratives with the Polish gaweda tradition and the English sailor's yarn, both related to oral story-telling. This paper sets out to look at one literary device — alliteration — found in early works narrated by Marlow (Youth, Heart of Darkness, and Lord Jim), and to indicate that various effects achieved by alliterative phrases (onomatopoeic, emphatic, rhythmical, and autotelic) all contribute to this narrator's status as an oral performer.
\end{abstract}


* Katedra Filologii Angielskiej Uniwersytetu Warmińsko-Mazurskiego w Olsztynie ul. Kurta Obitza 1, 10-725 Olsztyn e-mail: ewa.kujawska-lis@uwm.edu.pl 


\section{Marlow's narratives}

Joseph Conrad (1857-1924) created four works featuring the same narrator - Charles Marlow: a short story Youth published in 1902, a novella Heart of Darkness originally published serially in 1899, and then in a book-form together with Youth, a novel Lord Jim first released serially in 1899-1900, and then as a single volume in 1900, and finally a novel Chance which was printed in instalments in 1912 and then appeared in one volume in 1914. All these works are characterized by deliberately complex narrative structures, with stories within stories (a "Chinese box" narration) and multiple narrators. In each of them an anonymous frame narrator introduces an intradiegetic narrator, Charles Marlow, who in turn allows other narrators to tell their stories. Conrad privileged the diegetic aspect of his works, that is the very act of storytelling through which the events are communicated. Thus, the role of the narrators is very important in stressing the context of the narrative situation and never allowing readers to forget that they are being presented with a version of events mediated by particular narrators.

Marlow's prominent feature as a narrator is the manner in which he tells his stories, providing them with the status of oral tales. By profession he is a sailor and he spins his yarns in the company of a limited number of friends. The first two stories concern Marlow's personal experiences: in Youth he recounts his first voyage to the Far East as second mate on board the Judea; in Heart of Darkness he recalls his trip to the African Congo and his meeting with Kurtz there. The novels are centred on the lives of other characters, with Marlow remaining in the background: in Lord Jim Marlow narrates the story of the eponymous character and in Chance he focuses on the story of Flora de Barral and Anthony Powell. In each work, the extradiegetic narrator explicitly notes that Marlow will tell some tale, the only exception being Chance in which Marlow's story is in a dialogic relationship with the anonymous narrator. Marlow converses with the unnamed narrator and narrates events from Flora's life in the course of this exchange. Hence, with the largest number of dialogues, this novel has the least yarn-like character and will not be included in this analysis.

The genesis of Conrad's narrators, Marlow in particular, has been attributed to various literary influences, depending on the cultural and literary background of the critics. Polish 
critics, emphasizing the oral tradition as a model for Marlowian tales, attributed the narrative mode to Polish gaweda: "a kind of short story which has as a narrator an old, rather simple man, telling in a loose way and in colloquial language stories from old Polish life" (W. Weintraub qtd. in: Adamowicz-Pośpiech 2005: 42) ${ }^{1}$. One of the first critics to have pointed out gaweda as the possible source of inspiration for Conrad was Kazimierz Wyka who argued:

The teller of gaweda in bygone Poland left descendants. His great-great-great-grandson is Conrad's mouthpiece, Marlow (...). From his first book — more, indeed, in his early books than in his later ones - he consistently presented his narrative in the form characteristic of the gaweda of Polish romantic fiction. (Wyka 1946 [1969]: 65; trans. after Adamowicz-Pośpiech 2005: 43)

The same conclusions were formulated by Andrzej Busza (1966) and Wit Tarnawski, who additionally discussed analogies with the Arabian Nights, The Decameron and yarn (Tarnawski 1972: 32-36), all indicative of the stories-within-stories model. Characteristic features of these Polish fictitious storytellers, according to Wyka, included: a flair for an intriguing anecdote, an ability to vividly portray the events, skill in capturing the listener's attention, as well as intertwining the main story with reflections and personal memories (Wyka 1946 [1969]: 59), all of which can be found in Marlow's narratives.

Critics who inferred literary influences from the literature of the language in which Conrad created pointed to yarn. Morton Dauwen Zabel stressed: "the tradition of the «told story», the yarn, or saga of maritime tradition, was apparently (...) firmly rooted in his [Conrad's] mind by the time he took up writing" (1958: xvi). A more detailed analysis of the hallmarks of a told story convention found in Lord Jim was provided by Randall Craig, who highlighted the following elements: a fictitious situation of an oral performance (with the assumption of the existence of the teller and the listener) as well as the presupposition of values, experience and knowledge being shared by the teller and his audience (Craig 1981: 180-93).

Irrespective of the assumed influences, orality stands out as the feature of Marlow's narratives. As a narrator he often talks to his intradiegetic addressees directly, interspersing his narrative with such phrases as "you know", "you see”, "you say", "you remember", "you ought to know", "you understand", "I tell you", and "pass the bottle" (this last phrase appears only in Youth and is directly related to the narrative situation). The assumption that Marlow spins maritime yarns implies the employment of language appropriate for a sailor, i.e., both sailor's jargon and colloquial language. However, his language is far from being colloquial. Hence, Conrad was initially attacked for making Marlow too garrulous and too poetic and consequently the narrator's orality was questioned: "He has also occasionally made his spokesman employ phrases such as no oral story-teller would be likely to compass. (...) It is not thus that men speak" (review of Lord Jim, "Academy", 10 November

1 Though Polish critics largely accepted gaweda as one of the sources of the storytelling mode adopted by Conrad, Róża Jabłkowska referred the narrative structure of Lord Jim to the fragmentary nature and loose composition preferred by Laurence Sterne. She claimed that Conrad adopted and developed the Sternian mode of relating events and infused that with some Polish components (Jabłkowska 1961: 199-200). 
1900, in: Conrad: The Critical Heritage 1973: 117)². Conrad himself argued that his "style, which may be clumsy here and there, $(. .$.$) is perfectly straightforward and tending towards$ the colloquial" (letter to Alfred A. Knopf, 20 July 1913, in: Conrad: The Critical Heritage 1973: 161). Such critical opinions ignore the fact that Marlow's stories are not genuine sailor's yarns. Conrad was less interested in following generic conventions, than in the very act of storytelling with its epistemological importance. He gave prominence to diegesis over mimesis, and Marlow's utterances are not reproductions of reality. His storytelling is the act of organizing the told world and providing it with meaning. Thus his orality cannot be seen in terms of colloquial, concise language so that the narrative might fit the format of an after-dinner story unveiled at one sitting. Marlow's narratives, while exhibiting the characteristics of the yarn and gaweda, are related in language that is dominated by the poetic function, with metaphors, similes, and anaphors freely employed. One of the figures of speech that appears frequently in stories narrated by Marlow is alliteration which, as I wish to demonstrate, contributes to their orality.

The body of critical works devoted to Conrad's narrative methods is vast. Many new methodological approaches are incorporated in various critics' analyses, mostly Gerard Genette's theories, structuralism and post-structuralism. However, alliteration seems to be of little interest to these scholars. For instance, in his book devoted entirely to Marlow, Conrad's Marlow: Narrative and Death in "Youth", Heart of Darkeness, Lord Jim, and Chance, Paul Wake discusses Marlow as oral narrator, yet does not refer to this literary device (cf. Wake 2007). The main focus of the analysis is a link between death and narrative authority, but even in the chapter entitled "Marlow: 'Youth' and the oral tradition" which discusses diverse methods of Marlow's story-telling alliteration is not targeted. In his comprehensive discussion of Conrad's narrative techniques (Conrad's Narrative Method), based on an eclectic theoretical framework, in which he examines the relationship between narrative and thematic issues, Jakob Lothe mentions alliteration in passing. With reference to "The Tale", a short story of 1917, Lothe states that the authorial discourse is characterised, among other features, by "rhythmical patterns which include repetition and alliteration ('passionately interrupted and passionately renewed')" (Lothe 1989: 75). Though he begins his analysis of Conrad's narrative methods by comparing the use of Marlow in Heart of Darkness and Chance, and concludes that the former's narrative is more effective because of the interplay between Marlow as narrator and participant, he does not discuss alliteration as a device that may contribute to this effect. My wish here is, then, to demonstrate that alliteration is important for Conrad in creating his story-teller.

\section{Alliteration - general remarks}

Alliteration, from Latin ad litteram, is defined as "a rhetorical (stylistic) figure in which consonants are repeated in order to reinforce expressiveness" (Encyklopedia jezy)koznawstwa ogólnego 1993: 37) ${ }^{3}$. The repetition occurs at the beginning of words or stressed syllables (Cuddon 1991: 25), and preferably the words appear consecutively. Some scholars define

\footnotetext{
2 The review was unsigned, but Norman Sherry suggests that it might have been written by Edward Garnet (Conrad: The Critical Heritage 1973: 115), whereas Keith Carabine (Joseph Conrad: Critical Assessments 1992) identified the reviewer as Arnold Bennett.

3 Translations from Polish sources, unless indicated otherwise, are mine.
} 
alliteration more broadly as "the repetition of a sound in two or more words" (The Cambridge Guide to Literature in English 1988: 22), without pointing specifically to consonants. Alicja Okopień-Sławińska provides two perspectives on alliteration: a narrow one as a repetition of identical sounds or groups of sounds (no differentiation is made between consonants and vowels) at the beginning of words that appear consecutively in a verse or words that occupy analogical positions in a verse or sentence (Stownik terminów literackich 2000: 26) and a wider one as instrumentation in which words are purposefully selected and grouped in an utterance in such a way that some sounds are repeated more frequently than normally in close proximity (Stownik terminów literackich 2000: 214). The most incisive alliteration, however, is always the initial one (Śniecikowska 2008: 65).

Next to rhyme (including assonance and consonance), echolalia, glossolalia onomatopoeia, euphony, and homophony (cf. Stownik terminów literackich 2000: 119, 144-145, $182-$ $183,201,214-215,356-357,487-492)$, alliteration is one of the means that allow a writer to consciously shape the layer of sound in a literary work, both poetry and prose. Generally, alliteration fulfils three main functions: instrumentation, semantic and verse-creating (Stownik terminów literackich 2000: 26). First and foremost, it serves to highlight phonic features and to stress the expediency of the composition in terms of its sound organization (sound-layer shaping function - instrumentation). The semantic function is related to emphasizing through alliteration semantic relationships between similar sounding words. Alliteration makes such words stand out in a verse or sentence and may then be treated as a type of paronomasia that "uncovers hidden relationships between words" (Encyklopedia jezy/koznawstwa ogólnego 1993: 383). In such cases words function as sound allusions with relation to each other and "the phonic affinity created between them generates an impulse to juxtapose and compare their meanings" (Głowiński, Okopień-Sławińska and Sławiński 1972: 154). The verse-creating function of alliteration is directly related to constructing higher-order units by uniting separate verses or their parts, and alliteration must then be of a systemic nature.

The best known examples of alliterative verse come from old Germanic, English, Irish and Scandinavian poetry, and in its momentary instrumentation function alliteration has been employed in European poetry, including ancient Greek and Latin poems (Stownik terminów literackich 2000: 26). All Old English verse is alliterative and alliteration was employed instead of rhymes (The Cambridge Guide to Literature in English 1988: 22). Typically the verse was divided into two parts by a caesura, and each half-line had a specific number of stressed syllables (initially two) and an unlimited number of unstressed syllables. The rhythm of the alliterative verse was achieved through alliteration between both (sometimes one) of the stressed syllables in the first half and the first (sometimes the second) stressed syllable in the second half (Baldick 2001: 6). This can be illustrated with a fragment from Beowulf:

Fyrst forð gewat // Flota wæs on yðum,

bat under beorge. // Beornas gearwe

on stefn stigon; // streamas wundon.

(Beowulf, verses 210-212) 
In each verse the stressed syllables before the caesura begin with the same consonants as the first stressed syllable after it. During the times before end rhymes were used, such a phonic organization of the verses provided them with a rhythm necessary in oral literature. Following an alliterative revival in the late fourteenth century, other rhythmical and versification forms superseded alliterative verse, and alliteration began to be mainly used in its instrumentation and semantic functions.

As Polish theoreticians of literature claim, sound-shaping devices dominate in poetry and poetic prose (Głowiński, Okopień-Sławińska, and Sławiński 1972: 149), whereas in fiction alliteration is frequently overlooked or treated as a figure of speech that is perceived as a writer's display of creativity or linguistic skill. Nevertheless, it appears both in prose and fiction and recently Polish prose writers tend to attach more significance to it than in the past ${ }^{4}$. Nonetheless, the conscious shaping of the sound layer seems to be a feature of the so-called "non-epic fiction" — works characterized, among other features, by their poetic quality achieved through a specific linguistic organization of the text (Czapliński 1996: 69). "Non-epic novels" and "poetic model of fiction" are terms that were applied to the works of Polish 20 th-century writers ${ }^{5}$, and some contemporary Polish fiction writers appear to create in a similar vein, hence Przemysław Czapliński uses the term "non-epic model of fiction" to refer to their oeuvre (Czapliński 1996: 68) ${ }^{6}$. This model of fiction is based on the semantic activation of each textual element, thus the basic strategy is the transfer of poetic text organization to narrative fiction (Czapliński 1996: 72), with alliteration being one of the elements that shape the sound and lexical layers of such texts. Alliteration is particularly evident in the opening sentence of Zyta Rudzka's Biate klisze, immediately drawing the reader's attention ${ }^{7}$, and in Wojtek Hryniewicz's Tej rzeki nie prajde, in which it is accumulated in one sentence to such an extent that the sound layer becomes prominent, testifying to the pan-literary awareness of the writer and creating a text of poetic quality ${ }^{8}$. Alliteration can be a constitutive element of fiction, yet as Czapliński's analysis indicates, it appears in fiction that adopts the "non-epical mode" of writing. Although not directly referring to sound effects, Włodzimierz Bolecki indicates various ways in which "the poetic quality" (poéticité) is achieved and becomes functional in fiction. At the stylistic level, for instance, poéticité can be obtained via personification, animisation and anthropomorphization that transfer thematic aspects of the description

4 In English literature the situation is quite different: alliteration has been frequently employed in fiction, for instance by Charles Dickens in his Victorian "realist" novels and later by Gilbert Keith Chesterton in his novels and particularly in detective stories.

5 "Non-epic novels" (in Polish: nieepickie powieści) is a term applied to the works of Tadeusz Konwicki, while "poetic model of fiction" (in Polish: poetycki model prosy) was used in reference to some works created in the inter-war period, with the model continued by Miron Białoszewski, Leopold Buczkowski, Janusz Głowacki, Józef Loziński, Ryszard Schubert, and Donatan Kirsch, in which emphasis is placed on the language itself and its organization in the narrative text (Czapliński 1996: 68).

6 Czapliński employs the term "non-epic model of fiction" to describe the writings of Jerzy Plich, Magdalena Tulli, Zyta Rudzka, Natasza Goerke, Marek Bieńczyk, Aleksander Jurewicz, Marek Sieprawski, and Jan Sobczak (Czapliński 1996: 72).

7 “Adạm Kạdman przeczuwał, że począł się w Rosji”" (in: Czapliński 1996: 74).

8 "Mgła, mgła niczym powój pnie się puszystym powietrzem przez obszar ziemi, stanowiącej obecnie dzielnice miast, osiedla i wsie; nawleka na majestatyczny wzzór wiosennej zieleni korale nadchodzącej tęczy”" (in: Czapliński 1996: 75). 
to its language (Bolecki 1981: 75). To some extent, alliteration can also function similarly in prose writing. The prominence of alliteration in more "traditional" fiction is perhaps less significant as a constructive element, yet it can frequently be found there, especially in English literature.

\section{Alliteration in Marlow's narratives}

Conrad's use of alliteration was noticed and commented on by critics, though not really systematically studied. Referring to the beginning of Youth, John A. Palmer notices that "the words gather lyric force both by their controlled alliteration and by the mere denotative strength of the words themselves" (Palmer 1968: 18), indicating that the author quite consciously introduced alliterative passages. Ian Watt, however, claims that Conrad repeats sounds excessively (Watt 1981: 57) and attributes that to the writer's non-English origin. Referring to accidental alliterations and those consciously intended for effect and recognizing the writer's creativity, as in the sentence "the sinking sun would spread a glowing gold tinge", Watt argues that "Conrad would not have detected the awkward jingle as easily as a native speaker would have done" (Watt 1981: 57) ${ }^{9}$. When comparing Conrad's works with Vladimir Nabokov's novels, Adam Gillon notes: "Their styles, too, reveal similarities, especially in the propensity for literary allusion, alliteration, assonance, and generally a poetic use of prose" (Gillon 1994: 22). In his discussion of untypical collocations found in The Secret Agent, Allan Hunter provides examples of "the coupling of normally incompatible words", which are additionally reinforced by alliteration, that are "eminently memorable, and immediately arresting", such as "moribund murderer" (Hunter 2014: 159). He further enumerates such phrases as "senile sensualist" and "extraordinary expression" which create a comic effect; oxymoron: "swaggering spectre" and collocations of grotesque humour: "constitutional crawl" (Hunter 2014: 159), all of which contain alliterations that do appear to be consciously introduced.

Irrespective of their genesis (conscious or accidental), sound patterns are a significant element of Conrad's creative language, especially in the stories narrated by Marlow. Alliteration is a peculiar type of verbal emphasis. Its uniqueness lies in its double function in a literary text; that is, alliteration works at intradiegetic and extradiegetic levels, which is evident in works featuring Marlow. At the intradiegetic level the sound effect of alliteration is most prominent. In each story the context of the narrative situation is significant: Marlow spins his yarns in specific circumstances, when external stimuli are limited to the minimum. In Youth the company is sitting at the mahogany table that reflects the bottle, the claret-glasses and their faces. They are most likely in a pub or inn; no external sound is ever mentioned nor is other people's conversation, as if they were completely alone and focused only on Marlow's story. In Heart of Darkness Marlow speaks on the Nellie's deck through the night in complete darkness and in complete silence except for his voice. In Lord Jim the company is on the verandah, in deep dusk with the only source of light being fiery cigar-ends. The intradiegetic addressees of Marlow's stories concentrate only on what they hear and alliteration is significant for them as an emphatic patterning of sound. At the extradiegetic level alliteration creates additionally a graphic effect — readers notice that words begin with an identical letter, making specific words stand out in the sentence

$9 \quad$ I will return to this point in the concluding section of the paper. 
and drawing their attention. Intradiegetic narrators (both Marlow and other narrators) have no influence on the graphic layer of the texts; from their perspective alliteration is a means to expose the sound. The optical effect is an added value aimed at readers for whom the communication channel is the written text.

Marlow as a yarn-spinner draws the attention of his listeners (intradiegetic addressees) by various means. In order to be effective he has to constantly foster their interest in his story, sometimes introducing suspense, sometimes comical effects and sometimes operating through understatement. Although his syntax can be quite complex, his utterances are generally typical of spoken rather than written language; he employs colloquial expressions and idioms (though this does not mean that he does not resort to figures of speech), and provides individual linguistic stylization for the speech of other people he paraphrases or quotes. Idiolectal differentiation indicates that Marlow is mimicking the speech of other characters (especially foreigners) to keep his audience interested. He also pays attention to the sound layer through the use of phonetic stylistic figures, mainly onomatopoeias and alliterations, to reinforce the oral quality of his tales by reproducing sounds (onomatopoeia) or to emphasise some expressions and sounds (alliteration).

When narrating his stories Marlow ${ }^{10}$ makes different parts of speech (e.g. nouns, verbs, adjectives) alliterate in various configurations. Coordinate patterning is quite frequent, when words are either linked by conjunctions or not, for instance verbs: "Do or die" (Conrad 1948a: 5), "floundered and flopped" (Conrad 1948a: 108); adjectives: "pleased and proud" (Conrad 1948a: 22), "savage and superb” (Conrad 1948a: 135), "wild and withering contempt" (Conrad 1948b: 52), "startled, suffering facee" (Conrad 1948b: 84) ${ }^{11}$; participles: "battered and bandaged" (Conrad 1948a: 28) and nouns: "śleet, snow and a terrific sea" (Conrad 1948a: 6), "became a fixture, a feature" (Conrad 1948a: 15). Such patterning provides a rhythmic quality to the narrative, as if the teller was chanting. The most numerous group consists of a modifier followed by a noun: "śtolid souls" (Conrad 1948a: 25), "swwinging stroke" (Conrad 1948a: 27), "s savage sight” (Conrad 1948a: 132), "great gravity" (Conrad 1948a: 139), "fleshy figure” (Conrad 1948b: 21), "f́earless fellows (Conrad 1948b: 26), "blind brutality of impatience" (Conrad 1948b: 46), "silvery scream" (Conrad 1948b: 100), "burly back" (Conrad 1948b: 149), "śstubborn serenity" (Conrad 1948b: 151). In such cases it seems that when speaking extra emphasis is achieved in these words, but also an iambic rhythm when the alliterative words are two-syllable words. Occasionally, genitive of-phrases alliterate: "çargo of coal" (Conrad 1948a: 4), "pit of perdition" (Conrad 1948b: 45) and verbs followed by adverbs: "declared distinctly" (Conrad 1948b: 81), "stood stock-still” (Conrad 1948b: 89). Alliteration is frequently intensified by being

10 Alliteration is also used by other intradiegetic narrators, for instance Jim when he tells his version of the events, and the extradiegietic narrator in Lord Jim who is the main narrator in the five initial chapters a storyteller after all. Hence the examples provided are not exclusively Marlowian, yet the bulk of alliterations in the works analyzed appear in his speech.

11 Here additionally the /s/ sound appears in the noun "face"; since not all theoretical approaches to alliteration narrow it down to the beginning of words, but a wider understanding of it as a repetition of sounds intralexically is also admissible (cf. Stownik terminów literackich 2000: 26, 214-215), such repetitions are also highlighted here. 
doubled: "ștun'-sails set a alow and aloft" (Conrad 1948a: 3) ${ }^{12}$. Often the effect is accidental because the alliteration appears in typical collocations. However, increasing the number of words that begin with the same or similar sound testifies to a mindful sound patterning, mostly intended for an emphatic effect ${ }^{13}$.

In the analyzed works the phonosemantic qualities of some phrases may be related to the orality of the narrator who is attempting to play on the sense of hearing of his intradiegetic addressees, as if they were to experience the related events through hearing the sounds that accompanied them. Marlow demonstrates a special predilection for alliteration of words beginning with the alveolar sibilant /s/ or containing this sound: "The coasst of Patusan (...) is straight and sombre" (Conrad 1948b: 242), "śtubborn serenity" (Conrad 1948b: 151), "sober and set" (Conrad 1948b: 182). In these examples the sound itself of the alliterative consonant is apparently not laden with a special phonosemantic quality. But, as Reuven Tsur argues, "the sibilants /s/ and /š/ may have a busbing quality in one context, and a harsh quality (to varying degrees) in some other" (Tsur 2008: 2010; original emphasis). Consequently, different potentials of the same sounds may be realized depending on the context, and so "the sibilants /s/ and /š/ may have at some level of description features with noisy potentials as well as features with hushing potentials" (Tsur 2008: 211). One could argue that in these examples the hushing potential is realized. In other passages, alliterated words beginning with /s/, often accompanied with the voiceless palato-alveolar sibilant fricative /š/ []], a combination creating the onomatopoeic effect of hissing and quick movement in the air ${ }^{14}$, appear in the descriptions of storms (always accompanied with the hissing of winds): "stormy space surrounding us " (Conrad 1948a: 10), sea (humming and hissing even if calm): "splendour of sea and sky" (Conrad 1948a: 20), "sea sparkling" (Conrad 1948a: 33), sailing ship (the sound made by the ship may be indicative of hissing): "stores spoiled, ship strained" (Conrad 1948a: 14), burning ship (the sound of burning is also related to hissing): "smouldering shell of a ship" (Conrad 1948a: 25) and violent actions involving throwing (a spinning object produces a hissing sound): "shock sent him spinning" (Conrad 1948a: 24). In such cases the hissing sound (the harsh quality of varying degrees) corresponds to the meaning of the phrase, creating the phonetic-semantic relationship in which the noisy potential is most evident. Many of such alliterative phrases are found in Youth: this is a narrative entirely set on the sea and involving dramatic events, including storms and the explosion of the ship, following its smouldering for days.

12 Some of the examples provided are discussed in the context of their translation into Polish in my Marlow pod polske bandera. Tetralogia Josepha Conrada w preekeladach ₹ lat 1904-2004 [Marlow under the Polish Flag. Joseph Conrad's tetralogy in translations from 1904-2004] (2011).

13 My intention here is not to demonstrate that Conrad introduced alliteration much more frequently than his contemporaries or that he attributed alliteration with some novel, unknown before, qualities. Such a claim would require quantitative and qualitative research. The purpose here is to show that alliteration was used frequently enough to be a distinctive feature of stories narrated by Marlow and allowed the narrator to achieve certain effects related to his orality.

14 As Mirosław Bańko indicates, the fricatives $/ \mathrm{f} /, / \mathrm{v} /, \mathrm{s} / \mathrm{s}$, and $/ \mathrm{s} /$ appear in names of sounds that are associated with the movement of air or a quick movement of an object in air (Bańko 2008: 62). Thus, in Polish, for instance, the onomatopoeic sss, tsss, sy, ssy imitate the hissing of vipers, the sound of air released under pressure and appear in such words as syczéc, sykná́, and syk (Bańko 2009: 155, 157); sæšz, sæu imitate the constant sound made by flowing water or wind, as well as whispering and is found in related words, for instance: szumiéć, szum, szummy, szeleścić, szelest, szeptać, and szept (Bańko 2009: 162). 
Onomatopoeic effects, often created by alliterative words, work at both the intradiegetic and extradiegetic levels. Marlow's intradiegetic addressees listen to his voice and the sound of the words he selects allows them to "hear" the situation that he is describing. Often such passages rest on sound symbolism ${ }^{15}$. This is especially evident when alliteration is combined with enumeration that provides rhythm to the line, as in the depiction of water in the pipe during torrential rain: "The perforated pipe gurgled, choked, spat, and splashed" (Conrad 1948b: 181). The choice of alliterative sounds is significant. The repetition of the aspirated plosive /p/ imitates the popping sound of water bursting through the broken pipe $^{16}$, followed by hissing /s / which mimics the flow of water, and reinforced by /š in the last word. If this effect can be attributed to Marlow's skill as a storyteller and his orality, at the extradiegetic level it directs the readers' attention to the poetic quality of the description, producing both an onomatopoeic and aesthetic effect.

It seems unlikely that Conrad did not realize what effect was being created by strings of words in which the same or similar sound reappears in various positions (not only at the beginning, as is the case of most evident alliteration). Shaping the sound layer of his stories appears to be one of the ways in which Marlow as an oral performer desires to "hypnotize" his audience. His deliberate focus on sounds is evident in Marlow's recollections of sounds and voices he heard in Africa: "And I heard — him — it — this voice other voices - all of them were so little more than voices - and the memory of that time itself lingers around me, impalpable, like a dying vibration of one immense jabber, silly, atrocious, sordid, savage, or simply mean, without any kind of sense" (Conrad 1948a: 115). Marlow talks about voices that continue to be alive in his memory, creating a throng of sounds, which is amplified by alliterating adjectives at the end of the sentence, but also by the repeated /s/ sound throughout it. Again, the hissing quality of the utterance is foregrounded and relates to the semantic layer: the nature of sounds that Marlow heard in Africa is made chaotic, because he could not understand the language and all sound impressions mingled for him, turning into this overwhelming hiss.

Special emphasis on the sound layer has significant implications for the self-referentiality of the narratives. The narrators (be it Marlow or Jim or the extradiegetic narrator in Lord $\mathrm{Jim}^{17}$ ) absorb their addressees in their stories through narration dominated by the poetic function of language, which, obviously, is not something exclusively Conradian. However, the poetic function of language so evident in Marlow's stories indicates that he is not a typical gawedziarz or maritime yarn-spinner. As the Polish historian of literature and critic Józef Ujejski (1936: 193) stressed, in Marlow's narratives descriptions of nature, interiors and moods are composed in a literary manner par excellence to such a degree that one can doubt whether the story is told by a common sailor or written by a talented poet. Alliteration contributes both to the effect of the story told and an artistic text written. On the one hand, it emphasizes orality through echoing the tradition of oral poetry

15 Onomatopoeias, sound symbolism and iconicity are discussed in detail by Bańko (Bańko 2008).

16 The plosives /b/ and /p/ often appear in names of sounds associated with striking and explosion, with /b/ referring to louder and /p/ to milder sounds. In Polish, among words associated with such milder "explosive" sounds are those associated with water: plum, plusk (Bańko 2008: 61), though this is closer to the sound made by an object striking the water. Additionally, onomatopoeic prysk, pryskać, and prysnać name the sound of splashing, but also quick escape (Bańko 2009: 137).

17 In Youth and Heart of Darkness the role of the extradiegetic narrators is very limited. 
dating back in English to Anglo-Saxon literature. On the other, it creates aesthetic effects, especially in epithets and metaphors, for instance: "odious and fleshy figure" (Conrad 1948b: 21), "creepers clothing the low cliffs" (Conrad 1948b: 242), "blind brutality of impatience" (Conrad 1948b: 46), "silvery scream" (Conrad 1948b: 100), "an impression of pale plumpness in a frock-coat" (Conrad 1948a: 56). Such alliterations draw attention to the language itself, undermining the position of Marlow as a simple old sailor. He is none of the kind. Marlow's tale is internally focalised. It is filtered through, and presented from, his personal, subjective perspective and the language that he employs to do this cannot be equated with a mere sailor's sociolect. As an oral performer he resorts to a number of rhetorical devices that allow him to focus attention on himself, alliteration being one of them. The manner in which he speaks is equally important to what he speaks about. Marlow's orality cannot then be equated with mere colloquialism of spoken language. In his case, orality is the skill and ability to establish a relationship with his listeners (the intradiegetic narrator — intradiegetic addressees relationship), forcing them to surrender to the rhythm and sound of his speech.

\section{Concluding remarks}

Conrad's use of alliteration was attributed by Ian Watt to the writer's Polish origin. He argued that the writer's "difficulties with spoken English affected his style", one of the results being "an overemphatic patterning of words and sound" (Watt 1981: 57). He also suggested that "the excessive repetition of sounds" was related to the fact that Conrad "learned much of his English from reading rather than hearing" (Watt 1981: 57). This argument is quite problematic. Conrad's well-documented problems with spoken English were strictly connected with language production. The fact that Conrad had not actually heard some words spoken does not mean that he was unable to distinguish various sounds. Moreover, alliteration, despite primarily creating a sound effect, can be seen at the graphic level of the text. When writing, it is difficult not to notice that consecutive words begin with the same letter; Conrad may have had problems with distinguishing between words with silent letters at the beginning, like know, so occasionally he may have thought that he was creating alliteration, when he was not. However, his employment of alliteration seems to indicate that he consciously constructed the sound-layer in his works as one of the means to reinforce Marlow's orality (apart from the characteristics already mentioned in connection with gaweda and yarn).

Contrary to Watt's opinions, the manner in which Conrad learned English (mostly through reading) could actually be related to his tendency to use alliteration. This stylistic figure is often found in William Shakespeare's sonnets and Charles Dickens's prose ${ }^{18}$, which composed Conrad's daily readings at that time when he acquired the English language. In Polish prose that might have been known by Conrad alliteration is rather insignificant. The poetic language in the fiction of Bruno Shultz, Stanisław Przybyszewski and Tadeusz Miciński, characterized by linguistic experimentation, including alliteration, did not influence Conrad's writing. The Polish literary tradition is quite distinct from the English one; alliterative verse was practically unknown in Poland. Alliteration appeared occasionally in Old Polish poetry, but was not of a systemic nature. Assonance was quite

18 Just to give one example: "No warmth could warm, no wintry weather chill him" (Dickens 1940: 11-12). 
common in this poetry (Pszczołowska 1997: 29), and was particularly often employed by Mikołaj Rej during the Renaissance period (Pszczołowska 1997: 52). Instrumentation, mostly variations in rhyme patterns and assonance, but also juxtapositions of similar sounding expressions was typical of Polish Baroque poetry (Pszczołowska 1997: 52), in which the accumulation of various devices (enjambements, inversions, anaphors, syntactical parallelisms, and instrumentation — games with sounds) served to obscure the meaning and create riddle-poems (Pszczołowska 1997: 85). During the Enlightenment clarity and simplicity were most desired, correlative to the persuasive function of literature ${ }^{19}$. Neither in Classicism nor in Romanticism did alliteration emerge as a prominent feature. It was the Young Poland period that actually privileged excessive instrumentation, including repetitions of sounds, leading to the fuzziness of meanings (Pszczołowska 1997: 297). As Beata Śniecikowska stresses, many poems created in this period employed expressive and evident alliterations, mostly to create a specific mood in the poems (2008: 65). Although alliteration sometimes appeared momentarily in a single verse of poetry, and then had a purely ornamental function and exhibited the poetic skill of a particular poet (Pszczołowska 1997: 298) ${ }^{20}$, in this period it was one of the most frequently used devices contributing to the musicality of poetry ${ }^{21}$. Instrumentation, with much stress placed on alliteration, was a distinctive feature of Polish avant-garde poetry of the 20th century (futurism). Despite the heterogeneity of Polish futurism, what the works of all poets in this period share is the notion that the sounds of language are treated as the constructive material (Śniecikowska 2008: 530), which is so interesting in itself that the poet can experiment with it for its own sake. Alliteration was then a significant element in this experimentation $^{22}$. Nevertheless, in Polish literature alliteration has never had a systemic function as in English poetry (alliterative verse), and has been generally employed as an element of a momentary expression with an onomatopoeic function (Darasz 2001: 307).

Conrad was a voracious reader of Polish literature, but — for obvious reasons - his literary tastes were not shaped by the most illustrative examples of alliteration as used by the Young Poland and futurist poets. On 26 August 1915 he declared: "I surround myself with the Polish literature of long ago, Krasiński's, Mickiewicz's and Słowacki's. Their words are everything for me. I was raised and formed by them" (qtd. in: Szczypien 2017: 1). None of them used alliteration as a primary means of instrumentation, though Słowacki would introduce alliteration in a single verse (cf. Pszczołowska 1997: 289). Conrad read the works of Polish writers contemporary to him, especially those of Bolesław Prus, Stefan Żeromski, and Henryk Sienkiewicz, in which, however, alliteration was not a prominent feature. Having had no alliterative model in the native literature that shaped

19 The poetry of Adam Naruszewicz was quite unique; he - unlike his contemporaries — returned to Baroque poetry. His poem Do kominka features a line in which almost all words alliterate: "Tyś moim majem miluchnym" (in: Pszczołowska 1997: 166), but this is an exception rather than a rule.

20 This can be illustrated with a line from Leopold Staff's poem Poludnie włóczegi: "Kruże, w krysztalnym kruszcu kunsztownie kowane” (Pszczołowska 1997: 298).

21 The relationship between alliteration and musicality in the poetry of the Young Poland Movement is discussed in more detail by Beata Śniecikowska (Śniecikowska 2008).

22 Śniecikowska not only analyzes in detail various experiments with sound in Polish futurist poetry, but also provides numerous examples, many of them prominently featuring alliteration (Śniecikowska 2008). 
his literary tastes and having learned English on the basis of literary sources in which alliteration was frequent (both poetry and prose), Conrad may have formed the impression that alliteration is a necessary and typically used device in the English literary tradition.

Irrespective of the source of alliteration in Conrad's fiction, this device contributes to this writer's creative employment of language. The presence of alliterations in Youth, Heart of Darkness and Lord Jim demonstrates that, apart from accidental cases that can be found in any literary work, the author manipulates the language to achieve specific sound effects and to shape the stratum of word sounds and phonetic formations. He has his Marlow exploit possibilities offered by alliteration to create emphatic, onomatopoeic, rhythmical, and autotelic effects, all of which contribute to his orality. In his famous Preface to The Nigger of the "Narcissus" Conrad formulated his literary credo: "My task which I am trying to achieve is, by the power of the written word to make you hear, to make you feel - it is above all, to make you see" (Conrad 1950: XIV). The auditory element was significant to him and alliteration was one of many means he used to make his readers also hear through tales told by Marlow. The importance of alliteration and Conrad's awareness of it is evident in a comment that appears in Falk. The narrator, who in many respects resembles Marlow, states: "He was a Schiff-führer: Ship-conductor. That's how they call a Master Mariner in Germany. I prefer our way. The alliteration is good" (Conrad 1950: 147).

\section{Bibliography}

Adamowicz-Pośpiech Agnieszka (2005), The Mosaic Structure of "Lord Jim” [in:] Beyond the Roots: The Evolution of Conrad's Ideology and Art, ed. W. Krajka, East European MonographsMaria Curie-Skłodowska University-Columbia UP, Boulder-Lublin-New York.

Anonymus (1900 [1973]), Review of "Lord Jim" [in:] Conrad: The Critical Heritage, ed. N. Sherry, Routledge \& Kegan Paul, London-Boston.

Baldick Chris (2001), Oxford Concise Dictionary of Literary Terms, Oxford UP, Oxford.

Bańko Mirosław (2008), Wspótczesny polski onomatopeikon. Ikonicænośćw jezylku, PWN, Warszawa. - (2009), Stownik onomatopei, cayli wyrazón dźwieko- i rucho-naśladowczych, PWN, Warszawa.

Bolecki Włodzimierz (1981), Realistyczny i poetycki model prozy narracyjnej, “Teksty: teoria literatury, krytyka, interpretacje", nr 6 (60).

Busza Andrzej (1966), Conrad's Polish Literary Background and Some Illustrations of the Influence of Polish Literature on His Work, "Antemurale", no 10.

Conrad Joseph (1948a), Youth, Heart of Darkness, The End of the Tether: three stories, J.M. Dent and Sons, London.

- (1948b), Lord Jim, J.M. Dent and Sons, London.

- (1950), The Nigger of the "Narcissus"; Typhoon, Amy Foster, Falk, Tomorrow, J.M. Dent and Sons, London. 
Conrad: The Critical Heritage (1973), ed. N. Sherry, Routledge \& Kegan Paul, London and Boston.

Craig Randall (1981), Swapping Yarns: The Oral Mode of "Lord Jim", "Conradiana", no 13.

Cuddon J.A. (1991), The Penguin Dictionary of Literary Terms and Literary Theory, Penguin, London.

Czapliński Przemysław (1996), Nieepicki model prozy w literaturze najnowszej, "Teksty Drugie", no 5 (41).

Darasz Wiktor J. (2001), Perła po polsku, csyli próba przęktadu pewnej poetyki, “Język Polski”, no 4.

Dickens Charles (1940), A Christmas Carol, J.M. Dent \& Sons, London.

Encyklopedia jezyłkoznawstwa ogólnego (1993), ed. K. Polański, Zakład Narodowy im. Ossolińskich, Wrocław.

Gillon Adam (1994), Imitations of Imitations: Conrad's "Victory" and Nabokov's "Lolita" [in:] A. Gillon, Joseph Conrad - Comparative Essays, ed. R. Brebach, Texas Tech UP, Lubbock, Texas.

Głowiński Michał, Okopień-Sławińska Aleksandra, Sławiński Janusz (1972), Zarys teorii literatury, Państwowe Zakłady Wydawnictw Szkolnych, Warszawa.

Hunter Allan (2014), Joseph Conrad and the Ethics of Darwinism: the Challenges of Science, Routledge, London-New York.

Jabłkowska Róża (1961), Joseph Conrad, Zakład Narodowy im. Ossolińskich, Wrocław.

Joseph Conrad: Critical Assessments (1992), ed. K. Carabine, Helm, Robertsbridge.

Kujawska-Lis Ewa (2011), Marlow pod polska bandera. Tetralogia Josepha Conrada w preektadach z lat 1904-2004, Wydawnictwo Uniwersytetu Warmińsko-Mazurskiego w Olsztynie, Olsztyn.

Lothe Jakob (1989), Conrad's Narrative Method, Clarendon Press, Oxford.

Palmer John A. (1968), Joseph Conrad's Fiction: A Study in Literary Growth, Cornell UP, Ithaca, New York.

Pszczołowska Lucylla (1997), Wiersz polski. Zarys historyczny, Wydawnictwo Leopoldinum, Wrocław.

Stownik terminów literackich (2000), ed. M. Głowiński, T. Kostkiewiczowa, A. Okopień-Sławińska, J. Sławiński, 3rd. edition, Zakład Narodowy im. Ossolińskich, Wrocław.

Szczypien Jean M. (2017), "Sailing toward Poland" with Joseph Conrad, Peter Lang, New York. Śniecikowska Beata (2008), "Nuźw uhu”? Koncepcje dínięku w poezji polskiego futuryzmu, Wydawnictwo Uniwersytetu Wrocławskiego, Wrocław.

Tarnawski Wit (1972), Conrad. Cqłowiek — pisarz — Polak, Polska Fundacja Kulturalna, London. The Cambridge Guide to Literature in English (1988), ed. I. Ousby, Guild Publishing, London.

Tsur Reuven (2008), Toward a Theory of Cognitive Poetics, Sussex Academic Press, Brighton, Portland.

Ujejski Józef (1936), O Konradżie Korzenionskim, Dom Książki Polskiej, Warszawa.

Wake Paul (2007), Conrad's Marlow: Narrative and Death in „Youth”, Heart of Darkness, Lord Jim and Chance, Manchester UP, Manchester.

Watt Ian (1981), Conrad in the Nineteenth Century, University of California Press, Berkeley-Los Angeles.

Wyka Kazimierz (1946 [1969]), Czas powieściony [in:] idem, O potrzebie historii literatury. Szkice polonistyczne z lat 1944-1967, PIW, Warszawa.

Zabel Morton Dauwen (1958), Introduction [in:] J. Conrad, Lord Jim, Riverside Press, Cambridge, Mass. 